HSTC Bulletin

Journal of the History of Canadian Science, Technology and Medecine

hstc

Revue d'histoire des sciences, des techniques et de la médecine au Canada

bulletin

\title{
Sources in the History of Canadian Technology \#2
}

\section{Norman R. Ball}

Volume 2, numéro 2 (6), february 1978

URI : https://id.erudit.org/iderudit/1082371ar

DOI : https://doi.org/10.7202/1082371ar

Aller au sommaire du numéro

Éditeur(s)

HSTC Publications

ISSN

0228-0086 (imprimé)

1918-7742 (numérique)

Découvrir la revue

Citer ce document

Ball, N. R. (1978). Sources in the History of Canadian Technology \#2. HSTC

Bulletin, 2(2), 7-7. https://doi.org/10.7202/1082371ar d'utilisation que vous pouvez consulter en ligne.

https://apropos.erudit.org/fr/usagers/politique-dutilisation/ 
SOURCES IN THE HISTORY OF CANADIAN TECHNOLOGY \#2

Norman R. Ball

Although a great deal of acquisition work remains to be done in Canadian libraries and archives in the fields of the history of science and technology, some very good collections are already in captivity. Many of these are virtually unknown and poorly catalogued. Cataloguing and publicizing existing collections relating the science and technology are two great contributions librarians and archivists can make to the field. One such notable contribution was made recently by the University of Western Ontario when it published the catalogue to The Beatrice Hitchins Memorial Collection of Aviation History. Compiled by Marvin $W$. Hopkinson, and issued as Library Bulletin No. 9, this well-organized catalogue of over 90 pages is available by writing to:

Mr Edward Phelps, Librarian

Regional Collection,

Weldon Library,

University of Western Ontario

London, Ont.

The collection is the gift of the estate of the late Professor Fred H. Hitchins, aviation historian, who taught at UWO from 1960 to 1970. Professor Hitchins was Air Historian of the R.C.A.F. and an evaluation of the strengths, weaknesses and nature of the collection is given in the catalogue by W.A.B. Douglas, Director, Directorate of History at National Defence Headquarters, Ottawa. The catalogue and the collection consists of two major parts. The first is manuscript material. The second is printed works, primarily monographs on the history of aviation. One hopes that other libraries will follow the example set by Western.

***

The Public Archives of Canada has recently received what is undoubtedly the largest single existing source of biographical and professional information on Canadian engineers. The approximately 120 linear feet of membership files of the Engineering Institute of Canada start in 1887 and run to the present. They are part of the Engineering Institute of Canada Papers which were recently transferred to the PAC. The author is presently organizing and cataloguing the collection and a complete finding aid should be available in several months. In all cases the membership files give a summary of education and professional experience up to the date of application. In some cases these are supplemented by additional information such as obituaries or later career summaries. A further note regarding the extent and nature of the collection will be published soon. 